\section{PASIÓN Y POLÍTICA EN CATILINA DE GERTRUDIS GÓMEZ DE AVELLANEDA}

\author{
Yoandy Cabrera \\ Texas A\&M University \\ yoandyc@gmail.com
}

\section{PASSION AND POLITICS IN CATILINA BY GERTRUDIS GÓMEZ DE AVELLANEDA}

Cómo citar este artículo/Citation: Cabrera, Y. (2014). "Pasión y política en Catilina de Gertrudis Gómez de Avellaneda". Arbor, 190 (770): a188. doi: http://dx.doi.org/10.3989/ arbor.2014.770n6009
Copyright: (c) 2014 CSIC. Este es un artículo de acceso abierto distribuido bajo los términos de la licencia Creative Commons Attribution-Non Commercial (by-nc) Spain 3.0.
RESUMEN: En el presente artículo se propone una lectura de la obra Catilina (1867) de Gertrudis Gómez de Avellaneda. Primeramente se abordan algunas ideas generales con respecto a toda su obra literaria y a la recepción de la misma en España y Cuba, luego se hace énfasis en el valor de la imitatio como modo de creación, en el carácter ecléctico de la dramaturgia de la autora y en su diálogo personal y desenfadado con el neoclasicismo y el romanticismo. Por último analizamos los recursos dramáticos de la pieza y el tratamiento que se hace en ella de los conflictos pasionales y políticos.

PALABRAS CLAVE: Gómez de Avellaneda; teatro; Catilina; neoclasicismo; romanticismo; tragedia.
ABSTRACT: In this article, we suggest a reading of Catilina (1867) by Gertrudis Gómez de Avellaneda. First of all, we analyse some general ideas about her works as a whole and their reception in Spain and Cuba; we then emphasise the concept of imitatio as a type of creation, and also highlight the eclectic character of her play writing and her personal relationship with Neoclassicism and Romanticism. Finally we analyse the dramatic resources of this work and the treatment of passionate and politic conflicts.

KEYWORDS: Gómez de Avellaneda; theatre; Catilina; Neoclassicism; Romanticism; tragedy. 
La pieza teatral Catilina mueve a distintos debates en torno a la obra, el tiempo y el ambiente sociocultural vivido por Gertrudis Gómez de Avellaneda. Los principales presupuestos con los que puede asociarse este drama dentro del teatro y la sociedad en que se desarrolló la autora son: la relación u oposición que se estableció entre neoclasicismo y romanticismo, pues ella misma escoge de modo espontáneo y con mucha libertad de cada estilo lo que le parece valedero para su arte y sus propósitos; el cuestionamiento sobre su (falta de) interés en reflejar los problemas e inquietudes concernientes a Cuba y España, ya que gustaba de asuntos bíblicos, históricos y medievales; y por último la crítica a su gusto por recrear, reescribir textos de otros autores, hacer nuevas versiones y adaptaciones de los mismos, lo cual no era muy bien visto por algunos románticos que perseguían a toda costa lo que ellos consideraban "originalidad".

Por tanto, antes de entrar en el análisis de la obra dramática, trataremos estos razonamientos para explicar e ilustrar mejor la postura de Gómez de Avellaneda frente a dichos postulados, y para arrojar luz también sobre el valor y la lectura que merece una pieza como Catilina, pues al mismo tiempo puede ser considerada romántica y neoclásica, histórica y actual, versión de un original francés y a la vez reflejo de la capacidad inventiva y lírica de su autora.

\section{ROMANTICISMO Y NEOCLASICISMO}

Es lugar común entre la crítica literaria (Portuondo, 1930; Arrom, 1944; Leal, 1973; Prado Mas, 2004) que la obra dramática de Gertrudis Gómez de Avellaneda desde Leoncia (su primera pieza estrenada en Sevilla en 1840, cuya representación fue censurada y prohibida en Cuba) se considere ecléctica, dentro de un desarrollo romántico que persigue la libertad de los sentimientos sin renunciar o desdecir de algunos requerimientos estéticos neoclásicos. Sin embargo, como veremos, estas ideas tuvieron sus detractores.

El desajuste que significa la figura de Gómez de Avellaneda en las letras y la sociedad de su tiempo también tiene un eco en su teatro. Mujer que es llamada "mucho hombre" por Bretón de los Herreros, escritora que podía competir con los autores más consagrados y reconocidos de su tiempo, casada dos veces, que tuvo varios amantes, apasionada y libre dentro de lo que su tiempo le permitió, comparada con Safo con ironía y malas intenciones, con "cierta punta envenenada" (Méndez, 2007, p. 212), también, dentro de su amplio catálogo de clasificaciones trasgresoras entra la de dramaturga lírica, ya que mucho de su teatro de- biera ser leído como prolongación de su poesía, tanto en la forma como en el contenido. No debe entenderse un estudio de la lírica de Gómez de Avellaneda que no tenga en cuenta su teatro en verso; al respecto, declara José María Castro y Calvo:

Es muy curioso consignar que la poetisa no alcanzó tanta popularidad como la escritora de teatro. De Gallego, Quintana y Heredia había aprendido algo que le fue muy útil en uno y otro campos: el arte de versificar. Después de García Gutiérrez no hay otro que haya logrado el verso más perfecto y la metrificación más completa. (Gómez de Avellaneda, 1974-1981, t. I, p. 197).

En ese sentido, Catilina tiene un gran valor, pues el original francés de Alexandre Dumas y Auguste Maquet del que parte Gómez de Avellaneda está escrito en prosa y la escritora hace su versión en verso (octosílabos y endecasílabos), dando muestras de su gran capacidad y perfección versificadora y atribuyéndole a la métrica (como veremos) un valor conceptual y funcional que repercute incluso en la caracterización de los personajes. Alfonso Saura, al realizar un análisis comparativo de la pieza francesa y la de Gómez de Avellaneda, clasifica la versión de "gran ejercicio métrico" (Saura, 2006, p. 111).

Dentro del género dramático, Gómez de Avellaneda tampoco aceptó fáciles etiquetas, rompió con las clasificaciones manidas y esquemáticas, fue, ante todo, una neoclásica romántica. Mientras algunos veían una oposición insalvable entre un estilo y otro, entre la forma y la pasión, entre la métrica y la libertad, Gómez de Avellaneda vuelve a decirnos con sus piezas teatrales que nunca nada estuvo dividido de forma irresoluta, que se puede ser mujer y amante, apasionada y austera, sentimental y perfeccionista, romántica y neoclásica. Y así también se define su teatro en gran medida: cuidó de la forma y la versificación como pocos autores de su tiempo y a la vez sus personajes son movidos por fortísimas pasiones.

Dentro de esa trasgresión constante de formas y géneros, puede destacarse además el antiheroísmo en Saúl, la profundidad psicológica en el personaje, y principalmente la trasgresión de las rígidas unidades neoclásicas (tiempo y lugar), algo que, como veremos, también sucede en Catilina. Por tanto, Avellaneda no se hace eco de las unidades pseudoaristotélicas, no tienen sentido para ella, excepto la de acción que es consustancial a cualquier obra literaria. Lo que la autora toma del neoclasicismo es la preocupación formal, métrica, la limpieza en el decir, sin dejar de plasmar el ímpeto, el frenesí, el arrebato humanos. 
En efecto, como muchos de sus contemporáneos, conjugó ciertos postulados del "buen gusto" clasicista con el sentimiento y la pasión románticos. En el "Estudio preliminar" de la edición española de sus Obras en Madrid (1974-1981) José María Castro y Calvo apunta:

[L]o que se debe deducir, a través de su obra dramática, es la lectura del teatro clásico y el conocimiento del romántico inmediato. Mucho, por haberlo visto representar y, también, por haberlo leído.

Lo que no es fácil deslindar es la diferencia entre uno y otro y cómo se conjugan en la obra de la Avellaneda. (Gómez de Avellaneda, 1974-1981, t. I, p. 197).

Por otra parte, Avellaneda alcanzó en sus dramas un sólido equilibrio entre lo trágico y lo cómico y persiguió demostrar que, contrario a lo que pensaban muchos de sus contemporáneos, los argumentos medievales y antiguos eran propicios para escribir obras con presupuestos neoclásicos y con temas que mantenían total vigencia, aunque el asunto y el argumento fuesen distantes temporalmente.

\section{CATILINA Y EL CONCEPTO DE IMITATIO}

De las obras dramáticas escritas por Gertrudis Gómez de Avellaneda, unas cuantas tienen un referente literario o histórico como punto de partida. Los críticos y otros románticos recalcitrantes cuestionaron esas obras por su supuesta falta de originalidad. A pesar de ello, Avellaneda no dejó nunca de escribir piezas que fuesen parodias de una anterior, algo que fue práctica común en la literatura hasta el siglo XVIII y que ella hizo incluso con Catilina, una de sus últimas obras teatrales escrita "[e]n el ocaso de su actividad creadora" (Arcos, 2005, p. 264). Ya el propio Terencio, el dramaturgo romano, había tenido que defenderse de ataques semejantes en la antigüedad, porque sus enemigos, detractores y envidiosos cuestionaban su originalidad al partir de Menandro o al mezclar (mediante el proceso conocido como contaminatio) dos obras distintas en una nueva.

Pero, incluso, el tema de la "originalidad" es mucho más complejo en esta época, pues pasamos de la práctica milenaria de la imitatio (en el sentido de emular con una obra haciendo una versión personal de ella) a la búsqueda de la "originalidad". Es el siglo XIX la bisagra entre el concepto de retractatio (enfrentarse a un modelo establecido y superarlo en belleza, en imágenes y en el manejo del lenguaje en sentido general) y el de "originalidad" romántica. En el caso de la traducción, la "originalidad" ya se acerca a nuestra idea de fidelidad y cercanía con el texto de partida o hipertexto, cosa que para los autores precedentes poco importaba.

Con la llegada del romanticismo y la pretensión constante de buscar la originalidad, el concepto de imitatio cayó en descrédito y desuso, más conceptualmente que en la práctica, pues los autores no niegan la tradición, parten de ella, la rescatan, pero, como afirma Angel García Galiano:

$[\mathrm{H}]$ asta no hace muchas décadas, el concepto de la imitación poética entendida según los cánones renacentistas y antes clásicos, esto es, como imitación de los modelos, quedaba relegado por las retóricas y críticos al uso de una oscura zona de desprestigio, tal vez asumido tras la virulencia con la que se pronunciaron los románticos en defensa de la originalidad. De esa suerte, merced a la furia romántica y las corrientes críticas que acompañaron y sucedieron a este movimiento, la imitatio desapareció del favor general como postura literaria desde finales del siglo XVIII. Como digo, el eclipse de la imitación como vía de acceso a la creación artística ocasionó que dicho artificio comenzara paulatinamente a sentirse como algo ajeno al nuevo espíritu adalid de la espontaneidad y la autenticidad.

El concepto peyorativo de plagio y de apropiación literaria, heredado de la crítica decimonónica, ha contribuido durante muchos años a minusvalorar en los estudios críticos la influencia notable que las doctrinas de la imitación adquirieron en las obras de los poetas, y escritores en general, de los Siglos de Oro; y, lo que es más grave, a interpretar erróneamente los testimonios explícitos de los preceptistas del Renacimiento y del Barroco acerca de la validez de dicha doctrina poética, cuyo fervor fue tal en los siglos XV y XVI que provocó en toda Europa una marea de escritos dedicados exclusivamente a la elucidación de este concepto retórico. (Citado en Cabrera, 2011, pp. 59-60).

Esos prejuicios contra la imitatio y el valor de una versión fueron otros de los que tuvo que padecer Avellaneda, tanto en su teatro como en la lírica. Sin embargo, no cedió a las modas y a las restricciones del romanticismo como no lo hizo ante las absurdas y extremas pautas neoclásicas. De ambas posturas tomó lo que le pareció valedero, consciente de que, ni todo lo nuevo es "original" o mejor, ni todo lo antiguo es correcto o perfecto. Se movió con libertad entre las normas del "buen gusto" y los bríos indomables de lo romántico; por ello Avellaneda no traduce (en nuestro sentido actual), sino que imita, emula, versiona originales de Safo, Victor Hugo, Byron, Lamartine, Parny, Augusto de Lima... Y en el caso del teatro, lo hace con 
Dumas y Maquet al hacer una versión de Catilina desde el francés, o con Quintana en El príncipe de Viana. Al respecto, José Lezama Lima apunta:

Fue también la Avellaneda una excelente traductora. [...] No traduce la Avellaneda apegándose al texto con precisión rigurosa, son como ella las llama, imitaciones, varía los metros, mejora muchas veces el original, les comunica nueva elegancia y vigor. (Lezama Lima, 2002, p. 69).

Elegancia y vigor, mezcla de lo neoclásico y lo romántico, de la perfección formal y la espontaneidad de sentimiento. Cuando Fina García Marruz se refiere a Heredia citando a Martí, lo compara precisamente con Safo. Como la poeta arcaica griega, Heredia le parece a Marruz "arrebatado y armonioso" (Vitier y García Marruz, 1978, p. 20). Esos mismos calificativos son oportunos para definir a Avellaneda, no sólo en su poesía, sino en el teatro, que en gran parte puede ser leído como parte de su obra poética. La libre versión que realiza la autora en "Imitando una oda de Safo" del "Phainetai moi", la adaptación de la estrofa sáfica al soneto es un ejemplo de contención, armonía formal y también de exaltación, impulso, arrebato:
Ante mis ojos desparece el mundo,
y por mis venas circular ligero
el fuego siento del amor profundo.
Trémula, en vano resistirte quiero...
De ardiente llanto mi mejilla inundo...
ideliro, gozo, te bendigo y muero!
(Gómez de Avellaneda, 1869, p. 71).

Pasión sáfica y también muy suya, muy de sus personajes femeninos, como los de Fulvia y Aurelia en la versión de Catilina. Avellaneda supo leer hasta en sus imitaciones esa fuerza que encontraba en los otros y que era también reflejo de su propia personalidad y su temperamento.

Su Catilina es una versión del original francés homónimo cuyos autores fueron Alexandre Dumas y Auguste Maquet. Por esta y por otras obras, tanto líricas como teatrales, Gómez de Avellaneda fue cuestionada también, principalmente por ser, según algunos, mera imitadora de otros y no escribir en su lugar otras piezas teatrales "originales". Dichos presupuestos son de una limitación que la autora no aceptó y por su parte continuó escribiendo, traduciendo, versionando estas piezas cuando lo consideró necesario y pertinente, aunque fuese mal juzgada e incomprendida. Como en el caso de otras normas sociales o culturales con las que no estaba de acuerdo, Gertrudis fue fiel a su impulso y a su tendencia natural en este caso.

No obstante, que la traducción del original francés fuese de la prosa al verso, que de cinco actos Avellaneda crease cuatro, que no sólo redujera y variase la trama, la cantidad, la caracterización y la intervención de los personajes (de 26 a 21), sino que también su tendencia fuera llevar el discurso a la concisión del verso, la armonía y la concentración de la fuerza; son razones suficientes para que esta obra llamase la atención de la crítica y la misma dejase los esquematismos que paradójicamente el movimiento romántico (abanderado de la libertad) propagaba. No me detendré en una comparación exhaustiva entre la pieza de Dumas y Maquet con la versión de la autora cubana, lo cual merecería la pena, pero ello sobrepasa los objetivos de este trabajo. Baste con lo anterior y con señalar que también en la imitatio que lleva a cabo Gómez de Avellaneda hay lectura razonada, variación y aporte personal. ${ }^{1}$

\section{ANÁLISIS DE CATILINA}

El interés que puede despertar esta obra dentro de la producción dramática de la autora no está, en mi opinión, en las variaciones históricas o en la comparación con su referente francés, ni siquiera en el personaje de Carino (único niño presente en el teatro de Avellaneda) ni en el mismo Catilina que en un principio podría parecer el centro, pero en realidad es solo el eje de las pasiones que se mueven en escena. El interés está, en realidad, en las dos grandes fuerzas que mueven toda la acción y que propician las más importantes peripecias en la obra, las dos mujeres: polaridades enfrentadas por sus intereses, por un mismo hombre, por prevalecer. A ello se suma el conflicto político que encarnan Catilina vs. Cicerón.

Lucio Sergio Catilina (108-62 a.C.) era miembro de una familia patricia que se había empobrecido. Fue uno de los más importantes aliados de Sila. Además, se desempeñó como pretor en el año 68 a.C. y al año siguiente partió como gobernador hacia África, de donde regresó con no muy buena reputación por sus reiterados abusos de poder, y por ellos fue juzgado. Se presentó tres veces al consulado y la primera vez su candidatura fue retirada por dichos antecedentes. A la tercera vez, decidió organizar una conjuración contra el orden romano. La amante de uno de sus partidarios cuyo nombre era Fulvia informó a Cicerón de la conspiración. Entonces, Cicerón pronunció sus cuatro discursos conocidos como Catilinarias frente al senado, pero 
por falta de pruebas no puede juzgar ni condenar a Catilina. Por un fallo organizativo de los conspiradores, Cicerón consigue las pruebas que necesitaba para demostrar el complot conspirativo y, de forma sangrienta, va en contra de los organizadores que estaban en Roma aún. Catilina, para entonces, había marchado al destierro y fue muerto junto a $\mathbf{3 0 0 0}$ de sus hombres en Pistoia luchando contra el cónsul Cayo Antonio.

La conjuración de Catilina tiene en Roma varios antecedentes, desde las propuestas abortadas de leyes agrarias y reformas de Tiberio y Graco (que terminaron asesinados, 131-121 a.C.), la guerra civil entre el partido aristócrata y el popular, hasta la sublevación de Espartaco (73-71 a.C.); desde el consulado de Cinna y Mario (87-93) en que se tomaron medidas a favor de los plebeyos y el hostigamiento a muerte de los aristócratas, hasta la nueva instauración de la dictadura aristocrática con Sila (82-79 a.C.) que impidió cualquier intento de repartición de tierras que pudiese perjudicar a los patricios y llevó a cabo una persecución sangrienta contra los populares.

Roma había conquistado a esas alturas un buen número de territorios. Del descontento plebeyo que llevaba casi un siglo fomentándose, se aprovecha Catilina para intentar dar un cambio vertiginoso en la política romana, con el objetivo de destruir en su totalidad las formas de dominación y de gobierno existentes, el orden senatorial y las estructuras políticas, algo que en la obra de Gómez de Avellaneda Cicerón le echa en cara en uno de sus encuentros. Por su parte, como queda claro en la pieza teatral también, el orador representa el orden romano del momento, con el cual coincide y al que considera un logro que debe mantenerse, para ello está dispuesto a desenmascarar a Catilina frente a todo el senado.

En esencia, lo que cuenta la obra es lo siguiente: en el primer acto (que transcurre en la casa de Catilina) se descubren las dos líneas argumentales de la obra, por un lado la fragua y organización de la conjura contra Roma, la oposición de Cicerón (línea política), y por el otro las intenciones de Fulvia (amante de Catilina en el drama) de alejar a este de su hijo (Carino) y de su esposa Aurelia (línea personal y amorosa). En el segundo acto (que se representa en el escondite de la madre y el hijo) Aurelia y su Carino intentan huir, Catilina llega y se disipan los temores sobre sus intenciones contra el pequeño ${ }^{2}$, al que adora, pues Aurelia y su esclavo Clinias temían que quisiera matarlo. Los pone a salvo de los planes de Fulvia. Cicerón llega con la orden de destierro, pero Catilina no la acepta y se declaran un abierto enfrentamiento. En el tercer acto (que se de- sarrolla en la sala del templo de Telus donde se reúne el senado) Fulvia trama su venganza y decide desvelar la conjuración ante el senado, así, promete a Cicerón confesar. Ha hecho una copia del anillo de Catilina y le ha devuelto el falso. En el senado, Fulvia, contrariada, lo niega todo, Cicerón se queda sin pruebas y al darse los resultados de las votaciones, Catilina dice que marcha al destierro. En contra de la voluntad de Cicerón, recién reelecto cónsul, Catilina se va. En el cuarto acto (ubicado en el campamento del ejército de Catilina) este intenta apresurar la partida de Aurelia y Carino para ponerlos a salvo de las maquinaciones de Fulvia y de sus enemigos romanos. El niño marcha primero con Clinias, su esclavo; la esposa irá después. Fulvia utiliza su anillo para llevar a cabo su venganza: lo usa para hablar en nombre de Catilina, Clinias reconoce el anillo y da crédito a sus palabras (aunque esto se infiere y se refiere porque tiene lugar fuera de la escena). Aparece con un velo frente a Aurelia y le revela que su hijo está muerto. Cuando parece que Catilina y sus hombres van ganando, lo traen herido, conoce del asesinato de su hijo y muere en escena.

Catilina es una obra que no ha sido representada, la autora no se la entregó nunca a ningún teatro o director. Es una de las menos abordadas por la crítica, y de las menos estudiadas dentro de su producción dramática. Al principio de la obra, los invitados de Catilina hacen entrada al salón principal y comentan sobre la suntuosidad y la belleza. Entre ellos hay representantes populares, plebeyos, ediles a los cuales quiere utilizar el senador para ir contra el régimen de Roma. Algunos hablan con reserva, otros lo hacen convencidos de que deben dar su apoyo. Antes de que llegue Catilina, se comienza a hablar de la conspiración en ciernes, se dice que es un hombre cercano, afable, amigo de los pobres y oprimidos, aunque hay quien declara que sólo apoya a los seguidores de Sila. La referencia a Sila al principio y al final de la obra es uno de los elementos que le da circularidad.

Cuando Catilina entra a escena, ya estamos avisados: su trato es amistoso, cercano, simple. Se presenta como amigo de los pobres y como la esperanza del pueblo, confirma lo que sus aliados habían dicho momentos antes. Lo cierto es que poco a poco este populismo se va traduciendo en interés por los votos y más inmediatamente por el apoyo para ir contra Roma. Para eso quiere utilizar a las clases descontentas y más desfavorecidas, por ello también las trata de modo afable. Catilina es, desde su entrada, un gran actor, un embustero carismático. Comenzamos a ver sus dobleces cuando habla de justicia y promete a uno un cargo, a otro recompensas, etcétera. 
En la escena IV del acto primero aparece Stórax. Se nos dice que el esclavo entra presuroso, por lo que se puede declarar que este es una versión del servus currens de la comedia latina. Es este personaje que aparece en el primero y último actos el único elemento de comicidad y espontaneidad clara que permite decir que estamos ante un drama y no ante una tragedia, aunque el tono final de la obra y el desarrollo de la acción apunte a lo segundo. La investigadora Prado Mas en su tesis la clasifica entre las tragedias, aunque la autora la presenta como drama.

Stórax, como los esclavos de las comedias latinas, viene pidiendo protección, teme a la ira de su ama, Fulvia, la amante de Catilina. Al final de la obra, Stórax recibe parte de su recompensa por el apoyo que da a Catilina para poner a salvo a su hijo y sobresale en sus intervenciones por su sentido práctico, en parte cómico y por su hablar coloquial y espontáneo. Su aparición en el IV acto lo coloca también como elemento que une el principio con el final de la obra.

Al mismo tiempo, desde la escena IV del acto primero, se nos comienza a caracterizar a Fulvia sin que haya aparecido: "en sus venganzas/ es mi señora inflexible; / lo sabes, no tiene entrañas" (Gómez de Avellaneda, 1974-1981, t. II, p. 262). Así el esclavo descubre los propósitos de su ama de alejar a Aurelia y su hijo del padre por celos. Al final de la escena, convencido del desprecio que merece Fulvia, Catilina, sin embargo, se contiene, su sentido práctico le asegura que la necesita aún, que no debe dejar ver su decepción y su enojo.

El propósito siguiente será tranquilizar a Fulvia, mostrarle amor, entrega, hacerle un regalo (el anillo), tenerla contenta para que le dé tiempo a poner a salvo a su esposa e hijo. La escena siguiente (acto I, escena V) es, por tanto, otra muestra del histrionismo y de la manipulación de los que es capaz Catilina para lograr sus objetivos. Al mismo tiempo, Fulvia, en un largo parlamento, confirma y amplía lo que de ella había dicho su esclavo, pero, además, en medio de su ímpetu, declara su pasión y su incondicionalidad para con su hombre. Termina amenazándolo, al regalarle el anillo a ella como alianza. Le acota al recibir la prenda:
$Y$ ella me otorga un derecho
Por el cual queda desecho
Todo vínculo pasado.
No lo olvides; pues si alcanza
A gran altura mi amor.
¡Aún pudiera ser mayor
El vuelo de mi venganza!

(Gómez de Avellaneda, 1974-1981, t. II, p. 266).
Fulvia es, por tanto, desde su presentación, una mujer de pasiones extremas, tanto en el amor como en el odio, visceral y rotunda. En medio de estas declaraciones de amor y de principios, de amenazas cariñosas, hay una de las transiciones más interesantes de la obra: Fulvia cambia de tono totalmente cuando habla con su esclava Ismene sobre el plan contra Aurelia y el hijo de Catilina. Es el momento más claro en que se nota el contraste entre sus palabras frente a Catilina y sus planes ocultos. Ambos amantes, después de una escena de reconciliación y alianzas, siguen sus propósitos el uno contra el otro: él, salvar a su hijo y esposa; ella, alejarlos y deshacerse de los mismos para siempre. Lo que no sospecha siquiera es que la doblez es mutua. Catilina ha simulado no saber nada para ganar tiempo y le ha seguido el juego. Este pasaje evidencia el protagonismo que adquiere la "ironía trágica", el contraste entre las apariencias y la realidad en la pieza de Avellaneda, evidente para el receptor.

En las escenas VII y VIII del primer acto Fulvia participa de la conversación entre los hombres, lo cual también tiene que ver con el distinto tratamiento de la mujer en la sociedad romana con respecto a la sociedad griega, donde su participación era mucho más limitada. En paralelo, al final del cuarto acto, específicamente en la escena $\mathrm{XI}$, presenciamos una versión (podría decirse) del coloquio entre Héctor y Andrómaca: Catilina está a punto de partir para la batalla, Aurelia ha escuchado cuáles son sus propósitos: destruir por completo el orden actual romano; y esta le suplica por su hijo, para que desista, le recuerda que lo que pretende hacer desaparecer es también su pasado y sus ancestros, su historia, los suyos. A diferencia de Andrómaca en la Ilíada, Aurelia sí habla de temas políticos (como antes Fulvia), sí defiende su posición ante los hechos y las circunstancias sociales. Roma es, por tanto, en la obra, un tema común, sin distinciones: para amigos y enemigos, para hombres y mujeres, para populistas y aristocráticos, para patricios y plebeyos, lo cual hace que la pieza alcance una gran imbricación entre lo político y lo pasional, lo público y lo personal. El futuro de Roma es un hilo continuo y común para todos los personajes, y al devenir de esta está ligado el destino de todos los personajes, sin distinción, desde los esclavos hasta Cicerón, Catilina y el César.

Cicerón es el primero que se atreve a desenmascarar el populismo y el oportunismo de Catilina desde el primer encuentro que ambos tienen (acto I, escena IX). Pero el histrionismo de Catilina, como hemos visto, no es sólo con sus aliados ni en sus propósitos políticos y de poder. Del mismo modo engaña a Ful- 
via y a Aurelia. Los calificativos que Cicerón le da a su adversario son los mismos que sus mujeres le echan en cara: mentiroso, traidor, oportunista, tirano, manipulador, lo cual confirma y refuerza la imbricación entre lo político y lo pasional. Las mismas acusaciones que le hará Cicerón ante el senado son también las que erigen en la intimidad sus amantes en su contra. Y hasta el propio Catilina lo llega a reconocer.

Frente a quien único Catilina muestra toda su bondad e indefensión es ante su hijo. En la escena $V$ del segundo acto puede verse el único sentimiento puro de este gran manipulador, al único que no traicionaría es a Carino, ante él no tiene que actuar ni que ingeniar proyectos y estrategias. Ha traicionado a todos: a Roma, al César, a Cicerón, al senado, a Fulvia, a Aurelia. Pero no a su hijo. Ante él es el único momento en que Catilina depone el casco como si fuese una pesada careta. No necesita mentir, es el único episodio en que la transparencia y la sinceridad del personaje son totales, prístinas, genuinas. Ello contrasta, por supuesto, con el Catilina histórico que mató a su hijo, según cuenta Salustio (2001) (al decir: "tiénese por cierto que con la muerte de su propio hijo quitó el estorbo a tan execrable boda") y Cicerón (1994) que lo deja entrever en una pregunta velada ("¿no acumulaste a esta maldad otra verdaderamente increíble? ${ }^{3}$ Maldad que callo y de buen grado consiento quede ignorada, para que no se vea que en esta ciudad se cometió tan feroz crimen o que no fue castigado" (p. 19).

Mientras Cicerón y principalmente Salustio acusan a Catilina de haber matado a su propio hijo e incluso de matar a Aurelia para realizar un segundo matrimonio, Avellaneda mantiene viva a Aurelia, a su hijo, y presenta a Fulvia como amante de Catilina. En un primer momento, Aurelia decide huir con su hijo Carino lejos de Roma, donde estén a salvo del padre, pues cree que Catilina se aproxima para matar a su hijo. Pero esto no es más que una argucia fraguada por Fulvia para alejar de una vez a Aurelia y tener para ella a Catilina.

Movida por fuerzas diversas, por intensos y variados caracteres, la obra va de la multitud a las figuras aisladas: Fulvia, Aurelia, Catilina, Cicerón principalmente. Transitamos de la opulencia y el derroche, del espacio protegido y cerrado en el amplio y suntuoso salón de Catilina; al campo de batalla en que los mismos que inician la obra aparecen moribundos, heridos, y en que el gran anfitrión del inicio llega a morir gravemente golpeado, sangrante y recibiendo la peor noticia: la muerte de lo único puro y hermoso que había conservado, su hijo.
La ambición, la política, los celos, la pasión, los sentimientos fraternales, el odio, la venganza, la pureza, la perfidia se mezclan en una especie de mosaico polícromo, de friso que al mismo tiempo es una representación de Roma y de los comportamientos universales del ser humano que llegan hasta hoy. El tratamiento que Avellaneda hace a partir del referente francés del material histórico es el mismo que hizo Esquilo en Los persas. Como los trágicos griegos, Avellaneda no está interesada en la veracidad histórica, no persigue una representación fidedigna de los hechos, más bien encarna en sus personajes las fuerzas en oposición, tanto políticas como sentimentales, tanto externas (sociales) como internas (psicológicas). Por ello Fulvia deviene representación de la venganza y la pasión delirante, Aurelia es el espíritu maternal y la buena esposa sufriente encarnada, Cicerón es la representación de los intereses de la patria y la aristocracia y Catilina es la representación del buen padre, del tirano, del traidor (como amante y como ciudadano), del populista. Estos cuatro personajes son los que mueven y propician toda la acción en el drama.

En el caso de Catilina, se representa a un gran estratega, un ser práctico y analítico que busca el camino más rápido para llegar a su objetivo y, sin embargo, a pesar de sus cálculos, perece y padece la pérdida de lo que más ama: su hijo. Sus oponentes y sus campos abiertos son varios: Cicerón, Fulvia, Aurelia, parte del senado y de Roma, y contra todo ello tiene que maquinar y actuar al mismo tiempo.

Catilina, eje fundamental entre lo político y lo pasional en la obra, se erige como el gran embustero, el mentiroso de ambas partes, así lo llamarán sus dos mujeres y también Cicerón. Catilina miente en el amor y en la guerra, en el senado y en la intimidad. A pesar de su derrota y sus defectos, Catilina es el héroe principal de la pieza dramática. Alcanza la simpatía del lector/espectador.

Entre Fulvia y Aurelia hay sustantivas diferencias: Aurelia representa a la madre sufrida, que sabe perdonar, que todo lo hace por el bien de su hijo, consciente de su posición como mujer y como progenitora. Fulvia es un ser vengativo, cuya única ambición es tener a su lado a Catilina, por eso lo sacrifica todo y sin eso todo lo destruye. Mientras Aurelia declara: "amar / sólo he podido saber, / y llorar, y padecer, / y sufrir, y perdonar", Fulvia responde: "si tú amas y perdonas/ yo castigo y aborrezco" (Gómez de Avellaneda, 19741981, t. II, p. 317). En el encuentro de estas dos mujeres (acto IV, escena XIV) casi al final de la obra, la ironía de Fulvia es incisiva y cruel hasta límites insos- 
pechados. Ella sabe que para Catilina lo único puro e importante es su hijo, por lo tanto, la venganza contra él y Aurelia tiene que ser matarlo.

$\mathrm{Si}$, por una parte, como en el teatro neoclásico y griego, las acciones exteriores eran sólo narradas y aludidas en escena por los personajes, a pesar de los cambios de locación en este caso, tanto la batalla y la muerte de Carino son referidas y no representadas. No obstante, la incertidumbre, la manipulación irónica de la información que hace Fulvia vuelve más agónico y desesperante el desenlace. Por otra parte, como un guiño quizá al espíritu romántico y recordando al Áyax sofocleo, Catilina muere en escena. Aparece herido y ensangrentado como muchos otros de sus aliados. Esta mezcla continua de los recursos neoclásicos con las libertades románticas permite el contraste en estructura anular entre el inicio de la obra donde los hombres planificaban la conjuración, felices y despreocupados, y el desenlace mortífero en medio del campamento y la desolación.

La línea de lo político y lo pasional no está tan bien escindida como lo intenta mostrar en su análisis María Prado Mas. El destino de estas mujeres queda entrelazado, ligado irremediablemente al destino de Catilina y, por tanto, al de Roma. Ellas mismas participan, propician en la versión de Avellaneda los hechos más importantes que tienen gran repercusión en la conjuración, en el ambiente social y en los conflictos personales.

En cuanto a lo político, a la conjuración, el frecuente tratamiento de estos dilemas en el teatro de Gómez de Avellaneda es sin dudas un tema que le da a su lectura hoy total actualidad, además, debió ser visto por sus contemporáneos y debiera ser visto por la crítica posterior como un elemento universal que refleja las contradicciones sociales hasta el presente, tanto en Cuba como en España, así como en un amplio número de países. Catilina se erige como el defensor del igualitarismo (aunque en el fondo tenga otros intereses y ese sea sólo el medio para llegar al poder y beneficiarse), por su parte, Cicerón representa los intereses de la aristocracia, de la diferencia entre patricios y plebeyos, salvaguardando los bienes y privilegios de los primeros y la distancia entre ambos. Sin embargo, Cicerón, más parecido al personaje histórico, aparece como un hombre íntegro, convencido de sus ideas, dispuesto a defender los valores de Roma hasta las últimas consecuencias, mientras que Catilina persigue llegar al poder con el apoyo de los plebeyos e intenta usar a su favor la desventaja social y de derechos que tienen estos.
Para crear el triángulo amoroso y una de las oposiciones principales de la obra, Avellaneda convierte a la Fulvia histórica en amante de Catilina, cuando en verdad esta fue amante de uno de los conjurados, Quinto Curión. Es esta Fulvia la que informa a Cicerón de los propósitos y la existencia de la conspiración. Semejante triángulo amoroso es común en la obra literaria de Tula, la encontramos también, por ejemplo, en Leoncia y en su novela Dos mujeres.

En cuanto a las características formales y de estructura, esta obra tiene ciertas peculiaridades. Por una parte, está dividida en cuatro actos, cada uno de ellos ubicado en un lugar diferente, por lo que la variación constante y continua del espacio (que va de la casa de Catilina al campo de batalla) rompe con el presupuesto neoclásico y rígido de la unidad de espacio. Algo semejante sucede con la unidad neoclásica de tiempo, la obra se desarrolla a lo largo de semanas, y no dura, como lo exigían las leyes del buen gusto dieciochesco, sólo una jornada. La cantidad de personajes es grande, pues suman 21 en toda la obra y en las primeras escenas aparecen directamente cinco, por lo que podría considerarse otra trasgresión al academicismo neoclásico. Con respecto a la métrica, hay un elemento peculiar que ya habíamos anunciado: Avellaneda hace una clara distinción entre el metro principal de la obra en arte menor (el octosílabo) y el metro de arte mayor (endecasílabo) que utiliza cada vez que Cicerón y Catilina se enfrentan (acto I, escena IX; acto II, escenas VII-X; acto III, escenas XI-XIII) y con ese mismo metro se cierra la obra (acto VI, escena XVI).

El uso del endecasílabo entre los diálogos de estos dos importantes personajes tiene determinadas funciones objetivas en el sentido y el propósito de la obra: con este recurso formal la autora permite una extensión mayor y un alargamiento del ritmo, lo cual converge con las habilidades retóricas de Cicerón y también de Catilina. En cuanto al aspecto visual (que en la dicción se nota en el alargamiento silábico) Avellaneda establece una diferencia entre el par de opuestos Cicerón-Catilina y todos los otros personajes. Son dos posturas antagónicas enfrentándose, dando cada una las razones de su posición y defendiendo sus planes que son los planes, políticamente hablando, de dos Romas irreconciliables.

No debe dejarse a un lado la epicidad que tiene en la lengua española el uso del endecasílabo, principalmente en estrofas como la octava real; es este el metro en el que está escrito La araucana (poema épico hispanoamericano), Espejo de paciencia (poema épico cubano que inicia la literatura insular) y gran parte de la producción épica de otro poeta cubano, Manuel de Zequeira, entre la que podríamos destacar su "Batalla 
naval de Cortés en La Laguna" y "Ataque de Yacsi". Los agones entre Catilina y Cicerón son la representación de dos fuerzas ideológicas opuestas, en plena batalla, antagónicas, de ahí que cobre sentido este metro como reflejo del belicismo y el enfrentamiento. No hablan de la guerra en estos casos, la hacen, es el campo bélico con palabras, el verso como arma, como ataque. En el caso del final, el uso del endecasílabo le da el cierre heroico a la muerte de Catilina y de ese heroísmo se contagian todos los demás personajes que hablan con él.

Se ha dicho, más de una vez, que la venganza de Fulvia, al asesinar al pequeño, es desmesurada, injustificada, falta de "profundidad psicológica" por su deshumanización (Prado, 2001, p. 466). No me lo parece. Su antecedente, más cruel y vengativo aún, es Medea que mató a sus propios hijos. Incluso, en el devenir del teatro cubano, Fulvia y Aurelia pueden ser el referente decimonónico de dos arquetipos principales de la dramaturgia insular: por un lado, la mujer pasional y vengativa, que es capaz de las acciones más atroces cuando está en peligro o en juego su pasión, cuando algo atenta contra su realización amorosa (desde Cecilia Valdés y las distintas versiones teatrales que del personaje se han hecho ${ }^{4}$, que manda a matar a la novia de su Leonardo en medio de la ceremonia nupcial, hasta la María de José Triana en su Medea en el espejo, o la jabá y la santiaguera en Réquiem por Yarini de Carlos Felipe, por ejemplo), y por otra parte Aurelia representa a la esposa obediente, sufridora, resignada, imagen de la misma Virgen María, Mater dolorosa, madre coraje que todo lo sacrifica por su hijo y por su matrimonio. Figura que incluso podríamos relacionar con la ficcionalización que hace de sí misma Luisa Pérez de Zambrana en su poesía al llamarse "virgen que en el bosque vaga", al encarnar el "ángel del hogar", la "madre sufriente" (Chávez López, 2014) hasta las fieles y sacrificadas madres de obras como Casa vieja de Abelardo Estorino.

Estos paralelos que tienen como factor común el sacrificio los sustenta también Antón Arrufat en su análisis de Baltasar (1858) de Gómez de Avellaneda y Aire frío (1962) de Virgilio Piñera, entre los personajes femeninos Elda y Luz Marina. Como declara Arrufat, entre las dos obras "media un siglo", y:

Estas dos mujeres sin embargo y pese al tiempo, tienen algo en común. Volveré a decirlo sin exclamación y con una palabra que empieza a sonar a melodrama: el sacrificio. Como las heroínas clásicas, Ifigenia y Judith, Elda ha sido sacrificada por otros, en cambio Luz Marina se ha sacrificado por su propia voluntad. (Arrufat, 2008, p. 223).
Para concluir, se puede afirmar que con esta versión Gómez de Avellaneda continúa su interés y preocupación por entender y explicar el comportamiento humano, por las tiranías y las conspiraciones, tema muy recurrente en su dramaturgia, fundamental también en obras como El príncipe de Viana, Egilona, Flavio Recaredo, Baltasar, Oráculos de Talía... El uso del anillo u otro objeto como motivo y símbolo es un elemento que se repite en su literatura con cierta frecuencia, aparece además en El príncipe de Viana, Flavio Recaredo, Baltasar y Egilona, por ejemplo. Catilina es una obra que sobresale en su producción teatral por la perfección en la forma, por el uso y el contraste de los metros líricos y sobre todo por las grandes pasiones que representan Fulvia y Aurelia, por la dicotomía polarizada que encarnan Catilina y Cicerón entre populismo y aristocracia, fenómeno tan vigente en las sociedades de los siglos XX y XXI y en la historia de la Humanidad en general. Gómez de Avellaneda demuestra con esta versión en verso del original francés que no es fortuita su selección, sino que responde a intereses, valores e inquietudes que encontramos en gran parte de su teatro. Ya sea en una obra de tema bíblico (como Saúl) o histórico (como Munio Alfonso o la que nos ocupa), la autora no teme variar los acontecimientos para representar su cosmovisión, su noción de la sociedad y el entorno en que vivió. El referente legendario o histórico es para ella sólo la base, la justificación inicial y argumental para luego abordar los temas con cierta libertad. Como los dramaturgos del teatro clásico griego, prioriza no los hechos en sí, sino los móviles de sus personajes, el cómo y por qué sucede algo, y no el "qué ocurre" en un sentido meramente histórico o de aparente fidelidad a los acontecimientos. Gómez de Avellaneda usa la historia como los antiguos manejaban el mito en sus distintas versiones, con el fin de defender y representar una idea, un carácter, un mundo y una opinión propios. Catilina es, dentro de su búsqueda creativa, un paso valioso en ese engranaje interrelacionado que es toda su producción literaria.

\section{AGRADECIMIENTOS}

Quiero agradecer a Milena Rodríguez por su propuesta, sus sugerencias, su rigor y su fe en mí para participar en este número de Arbor en homenaje a Gertrudis Gómez de Avellaneda por el bicentenario de su natalicio, y a los trabajadores de la Biblioteca de la Agencia Española de Cooperación Internacional para el Desarrollo (en Madrid) en la que consulté gran parte de las obras que utilicé para escribir este artículo. 
1 Sobre la comparación del original francés con la pieza de Gómez de Avellaneda, puede consultarse el artículo de Saura (2006).

2 Aurelia y su esclavo Clinias temen los propósitos de Catilina, pues habían sido avisados por la esclava de Fulvia (Ismene) de que este pretendía matar a su hijo. Ello podría recordar al Catilina histórico, que sí mató a su hijo e incluso a su esposa,

\section{BIBLIOGRAFÍA}

Arcos, J. L. (2005). Historia de la literatura cubana. La colonia: desde los orígenes hasta 1898. La Habana: Letras Cubanas.

Arrom, J. J. (1944). Historia de la literatura dramática cubana. Connecticut: Yale University Press.

Arrufat, A. (2008). Las máscaras de Talía. Matanzas: Ediciones Matanzas.

Cabrera Ortega, Y. (2011). La poesía anacreóntica en Cuba. Traducción e imitación [Tesis de magister inédita]. Universidad Complutense de Madrid. Madrid.

Chávez López, F. E. (2014). La claridad en el abismo: la construcción del sujeto romántico en la poesía de Luisa Pérez de Zambrana. Madrid: Verbum.

Cicerón. (1994). Catilinarias. Barcelona: Planeta. pero en la versión de Avellaneda dichas pretensiones quedan solo como rumor pues el personaje Catilina en la pieza teatral ama ciega y fervorosamente a su hijo.

3 El asesinato del hijo de su primera esposa, como apunta en su edición Pere J. Quetglas (Cicerón, 1994, p. 19).

4 Aunque la primera versión de Cecilia Valdés o la Loma del Ángel de Cirilo

Espinosa, N. (2004). La virgencita de bronce. La Habana: Ediciones Alarcos.

Estorino, A. (2003). Teatro escogido. La Habana: Letras Cubanas.

Gómez de Avellaneda, G. (1869). Obras literarias. (tomo I). Madrid: Imprenta y Estereotipia de M. Rivadeneyra.

Gómez de Avellaneda, G. (1974-1981). Obras. Madrid: Atlas.

Leal, R. (1973). El teatro de Gertrudis Gómez de Avellaneda. La Habana: Consejo Nacional de Cultura.

Lezama Lima, J. (2002). Antología de poesía cubana ( 2 ed.). Madrid: Verbum.

Méndez, R. (2007). Otra mirada a La Peregrina. La Habana: Letras Cubanas.

Portuondo, J. A. (1930). Bosquejo histórico de las letras cubanas. La Habana: Ministerio de Educación.
Villaverde es en prosa y además es anterior (1839, la segunda y definitiva es de 1882) a Catilina (1867) de Gómez de Avellaneda, sin dudas la versión de Gonzalo Roig (zarzuela de 1932), la pieza teatral de Estorino titulada Parece blanca (2003) y la de Norge Espinosa para títeres (La virgencita de Bronce, 2004) dialogan con el personaje de Fulvia y su pasión vengativa.

Prado Mas, M. (2004). El teatro de Gertrudis Gómez de Avellaneda. [Tesis doctoral inédita]. Universidad Complutense de Madrid. Madrid. Recuperado de http://eprints.ucm.es/tesis/fll/ucmt25107.pdf

Salustio (2001). La conjuración de Catilina Guerra de Yugurta. Madrid: Akal.

Saura, A. (2006). Gertrudis Gómez de Avellaneda, adaptadora teatral. Çédille. Revista de estudios franceses, 2, pp. 103-113.

Villaverde, C. (1882). Cecilia Valdés o la Loma del Ángel. New York, Imprenta de El Espejo.

Vitier, C. y García Marruz, F. (1978). Flor oculta de poesía cubana. La Habana: Arte y Literatura. 